\title{
E7 Ülkeleri ile Türkiye Arasındaki Dış Ticaretin Panel Veri Analizi: Çekim Modeli Yaklaşımı'
}

\author{
Makber TEKIN (https://orcid.org/0000-0001-5817-2962), Akdeniz University, Turkey; \\ makbertekin@akdeniz.edu.tr
}

Fahriye MERDIVENCI (https://orcid.org/0000-0001-8956-7051), Akdeniz University, Turkey; fahriye@akdeniz.edu.tr

\section{A Panel Data Analysis of Foreign Trade Between E7 Countries and Turkey: The Gravity Model Approach ${ }^{2}$}

\begin{abstract}
According to the Gravity Model, international trade should be explained based on GDP and geographical distances among countries. This study aims to determine the factors affecting global trade volume among Turkey and E7 countries and test whether the Gravity Model is suitable for explaining the trade volume using panel data analysis. Linder and population variables that are expected to affect the foreign trade were used as explanatory variables in the model. The study results confirmed that the variables in the gravity model significantly explained international trade among Turkey and E7 countries between the years 2000-2018. According to the results, the international trade of Turkey to E7 countries is positively and significantly related to the GDP and the population variables. Moreover, distance due to geographical location was negatively and significantly linked to international trade.
\end{abstract}

Keywords $\quad$ : International Trade, E7, Gravity Model, Panel Data Analysis.

JEL Classification Codes: F1, F120, C33.

$\ddot{\mathbf{O z}}$

Çekim Modeline göre ülkeler arasındaki dış ticaret, GSYH ve ülkeler arasındaki mesafe değişkenleriyle açıklanabilmektedir. Bu çalışmanın amacı, Türkiye ve E7 ülkeleri arasında gerçekleşen ticaret hacmine etki eden faktörleri belirlemek ve Çekim Modelinin ticaret hacmini açıklamaya uygunluğunu panel veri analiz ile test etmektir. Dış ticaret ilişkisini etkilemesi beklenen Linder ve nüfus ise modelde açıklayıcı değişkenler olarak kullanılmıştır. Araştırma sonucunda, 20002018 yılları arasında Çekim Modeli değişkenlerinin Türkiye ve E7 ülkeleri arasındaki ticaret hacmini anlamlı bir şekilde yordadığı bulunmuştur. Buna göre Türkiye'nin E7 ülkeleri ile gerçekleştirdiği ticaret ilişkisi, GSYH ve E7 ülkelerinin nüfusları ile pozitif ve anlamlıdır. Ayrıca dış ticaretin, mesafe ile negatif ve anlamlı ilişkisinin olduğu görülmüştür.

Anahtar Sözcükler $\quad$ : Uluslararası Ticaret, E7, Çekim Modeli, Panel Veri Analizi.

1 Bu çalışma, Akdeniz Üniversitesi Sosyal Bilimler Enstitüsü'ne Arş. Gör. Makber TEKIN tarafindan sunulan “Türkiye'nin E7 Ülkeleri ile Gerçekleştirdiği Dış Ticaretinin Çekim Modeli Yaklaşımıyla Analizi” başlıklı yüksek lisans tez çalı̧̧masından üretilmiştir.

2 This study is derived from Res. Asst. Makber TEKIN's master's thesis called "The Gravity Model Approach to Analysis of Foreign Trade Conducted with Turkey and E7 Countries", presented at the Institute of Social Sciences of Akdeniz University. 
Tekin, M. \& F. Merdivenci (2022), “E7 Ülkeleri ile Türkiye Arasındaki Dış Ticaretin

Panel Veri Analizi: Çekim Modeli Yaklaşımı", Sosyoekonomi, 30(51), 407-426.

\section{Giriş}

Küreselleşmenin uluslararası ticareti artırıcı etkisi ülkeleri ekonomik büyümeye teşvik ederek ülkelerin diş ticaret faaliyetlerine ağırlık vermelerini ve karşılıklı dış ticaret akışları gerçekleştirmelerini sağlamaktadır (Khandare, 2011: 4). Gerçekleşen diş ticaret akışları genellikle ülkelerin ekonomik merkezleri arasındaki bağlantıların bir göstergesi olarak kabul edilmektedir (Paas, 2003: 1). Uluslararası ticareti ve ticaret akışlarının kapsamını ekonomik büyüklük ve uzaklık açısından analiz etmek amacıyla son zamanlarda Çekim Modeli yaklaşımı yaygın olarak kullanılmaktadır (Anderson \& Wincoop, 2003: 170). Model, ülkelerin ekonomik büyüklüğünü temsil eden GSYH rakamları ve aralarındaki mesafeden dolayı kaynaklanan uzaklığa göre farklılık gösteren taşıma maliyetleri ile kurulmuştur. Ayrıca model yapısı itibariyle uluslararası ticareti birçok değişken açısından analiz etmeye firsat vermektedir.

Alan yazınında model ile yapılan birçok çalışma mevcuttur. Bu çalışmalar genellikle ülkeler arasında gerçekleşen ticaret akışlarını Çekim Modeline çalışmanın amacı doğrultusunda eklenmiş kukla değişkenlerle analiz etmektedir (bkz. Aitken, 1973; Thursby \& Thursby, 1987; Wall, 1999; Nitsch, 2006; Baytar, 2012; Işık, 2016). Genel olarak çalışmalarda modelin ticaretin kapsamını ve niteliğini açıklamada kullanılabileceği belirtilmiş ayrıca modelin analiz gücünün yüksek olduğu vurgulanmıştır (Paas, 2000: 636). Türkiye'nin E7 (Gelişmekte Olan Yedi Ülke) ülkeleri ile artan dış ticaret rakamları son yıllarda artış göstermekle beraber 2018 itibariyle 64.263 milyar dolardır (World Bank, 2020). Artan dış ticaret rakamları ve literatürde bu ülkeler ile gerçekleşen ticaret akışını güncel veriler ile ele alan çalışmaların sınırlı olması çalışmanın temel motivasyonudur.

Bu çalışmada ele alınan “Gelişmekte Olan Yedi Ülke” (E7) son zamanlarda yüksek dış ticaret hacmine sahip olmakla beraber sermaye piyasaları hızlı bir şekilde artış gösteren ve resmi bir bloklaşma olmayan ülke grubunu temsil etmektedir. E7 ülkeleri arasında Çin, Hindistan, Rusya, Brezilya, Meksika, Endonezya ve Türkiye yer almaktadır. E7 “Gelişmekte Olan Yedi" kavram ilk olarak saygın bir muhasebe firması olan Price Waterhouse Coopers (PWC) tarafindan 30 Ekim 2006'da yayımlanan Stern Review raporunda (Samadder et al., 2012: 12) kullanılmıştır. PWC danışmanlık firmasının 2006 yılında yayımladıkları "The World in 2050" (2050'de Dünya) başlıklı araştırma raporu, gelişmekte olan ekonomilerin performanslarını ve 2005 'te başlamış olan ekonomik dağılımdaki değişiklikleri göz önüne alarak, gelecek 45 yılı içeren bir gözlemlemeyi içermektedir. Firma 2008 yılında 2050'de olası ekonomik dağılımları ele alarak ülkelerin gelecekteki ekonomik performanslarını savunabilmek adına güncel olan ekonomik verileri ve nüfus artış oranlarını referans alarak tahminlerini güncellemiştir (PWC, 2008: 5-8). Çalışma BRIC’in (Brezilya, Rusya, Hindistan ve Çin) yanı sıra, olağanüstü bir performans göstermesi beklenen diğer ülkeleri de ele almaktadır. Çalışmadaki öngörüler, ülkelerin büyüme çabalarının sonuçlarının olumlu olduğu ve beklenmeyen ekonomik, politik ve doğal sorunların ortaya çıkmadığı varsayımı ile yapılmıştır (Medina, 2010: 5). Firma 2017 yılında yayımladıkları "The World in 2050: The Long View How will the Global Economic Order Change by 2050?" başl1kl1 raporunda ise E7 ülkelerinin 1995 yılında G7 ülkelerinin yarısı kadar ekonomik büyüklüğe sahipken 
2015 yılında aynı büyüklüğe ulaştığını ve 2040 yılında G7 ülkelerinin iki katı büyümesinin mümkün olduğunu belirtmiştir. Bu ülkelerin hızlı büyüme eğilimlerinden dolayı gelecek yıllarda ülkelere yapılacak yatırımların artacağı öngörülmektedir. Ayrıca raporda ülkelerin arasında yer alan Türkiye'nin 2050 yılına kadar \%3'lük oranla Avrupa'nın en hızlı büyüyen ekonomisi olacağını belirtmiştir. Raporda dünyadaki GSYH’nin \%85'ini oluşturan, dünyanın en büyük otuz iki ülkesi için 2050 yılına ulaşan en uzun vadeli küresel büyüme tahminleri de yayımlanmıştır. Bu rapordaki tahminler doğrultusunda küresel ekonomik güç sıralamasında 2016 yılında Çin bir, Hindistan üç, Rusya altı, Brezilya yedi, Endonezya sekiz ve Türkiye on dördüncü sırada yer alırken 2050 yılında Çin'in bir Hindistan'ın iki, Endonezya'nın dört, Brezilya'nın beş, Rusya'nın altı, Meksika'nın yedi ve Türkiye'nin on birinci sırada yer alacağı tahmin edilmiştir (PWC, 2017: 4-9). Bu nedenle son zamanlarda ekonomik büyüme performanslarındaki başarılarından dolayı bu çalışmada E7 ülkeleri ele alınarak Türkiye'nin bu ülkelerle gerçekleştirdiği dış ticaret hacmi analiz edilmiştir.

Çalışmanın temel amacı, Türkiye ve E7 ülkeleri arasında gerçekleşen ticaret hacmine etki eden faktörleri belirlemek ve Çekim Modelinin ticaret hacmini açıklamaya uygun olup olmadığını panel veri analiz ile test etmektir. Bu doğrultuda çalışmada ikinci bölümde Çekim Modeli teorisinin ortaya çıkışı ve teorik altyapısı hakkında bilgi verilmiştir. Üçüncü bölümde uluslararası ticaret alanında dış ticaret akışlarını Çekim Modeli ile açıklayan çalışmalara ilişkin literatür taraması yapılmıştır. Dördüncü bölümde veri seti ve değişkenler, temel Çekim Modeli olmak üzere toplamda üç farklı şekilde kurulan analiz modeli ve analiz prosedürü ele alınmıştır. Beşinci bölümde analiz sonucunda elde edilen bulgulara yer verilmiştir. Son olarak sonuç bölümünde araştırmanın bulguları ele alınarak değerlendirme ve öneriler yapılmıştır.

\section{2. Çekim Modeli}

Bölgelerin ekonomik merkezleri arasındaki ilişkilerin bir göstergesi olarak kabul edilen uluslararası ticaret akışları, ekonomik ve mekânsal kavramlar arasındaki bağlantıları temsil eder. Bu durum doğrultusunda uluslararası ticaret akışlarının incelenmesi için "ülke çifti arasındaki ticaret akışını, ekonomik kütleleri (milli gelir) ile orantılı ve aralarındaki mesafeyle ters orantılı olarak" açıklayan Çekim Modeli yaklaşımı son yıllarda yaygın olarak kullanılmaktadır (Paas, 2003: 1-7). Çekim Modeli ilk olarak Tinbergen (1962), Pöyhönen (1963) ve Linneman (1966) tarafından tanıtılmıştır (Porojan, 2001: 265; Nguyen, 2009: 267; Kepaptsoglu et al., 2010: 1). Tinbergen (1962) ve Pöyhönen (1963) modeli, Avrupa ülkeleri arasında gerçekleşen ikili ticaret akış kalıplarını incelemek için kullanmıştır. Linneman (1966), Çekim Modelinin teorik temeline eklemeler yaparak modeli genişletmiş ve Walrasian Modelini kıstas olarak kullanıp Çekim Modeli denkleminin teorik temellerini açıklamıştır (De Benedictis \& Taglioni, 2011: 55-56). Yapılan bu çalışmalardan sonra model, uluslararası ticaret alanında özellikle ülkeler arasında gerçekleşen ticaret akışlarını analiz etmede sıklıkla kullanılmıştır (Deardroff, 1998: 7; Leamer \& Levinshon, 1995: 4445). 
Uluslararası ticaret alanında önemli ve popüler olan Çekim Modeline yönelik yapılan eleştiriler arasında teorik temelinin yetersiz olması yer almaktadır (Bergstrand, 1985: 474; Kimura \& Lee, 2006: 94; Stack, 2009: 775). Deardorff (1998), bu eleştirilerin doğru olmadığını ve 1970'lerin ikinci yarısından itibaren teorik altyapısının genişletilip geliştirilmesi adına kuramsal altyapısına katkıda bulunan pek çok çalışmanın olduğunu belirtmiştir. Bunlar arasında Anderson (1979), ürün farklılaştırmasını varsayan Armington (1969) varsayımından Çekim Modeli denkleminin teorik temelini türetmiş, Bergstrand (1985, 1989) ise modele, mikroekonomik temel geliştirmiştir. Ayrıca karşılıklı ticaret akımlarında belirleyici faktörleri incelemiş ve modeli, Tekelci Rekabet Teorisiyle açıklamıştır.

Helpman ve Krugman (1985), Çekim Modeli denkleminin ölçeğe göre artan getiri ile tekelci rekabet modelinden, Deardorff (1998), ürün farklılaşması dikkate alınmadan Heckscher-Ohlin modelinden de türetilebileceğini göstermiştir. İlerleyen zamanlarda yapılan çalışmalardan Eaton ve Kortum (2002) ise modeli, Ricardo'nun teorisi ile açıklamıştır. Yapılan bu çalışmalardan sonra Çekim Modelinin Heckscher-Ohlin ve Tekelci Rekabet Modelleri dahil olmak üzere farklı modellerden türetilebileceği kabul edilmiştir (Kimura \& Lee, 2006: 94). Son olarak Anderson ve Van Wincoop (2003)- Anderson (1979), çalışmasını temel alıp geliştirerek- ikili ticaret akışının hem ikili düzeyde var olan ticari engellerden hem de bu engellerin diğer tüm ülkelere göre göreceli ağırlığından etkilendiğini göstermiştir (Benedictis \& D. Taglioni, 2011: 64).

\subsection{Basit (Illkesel) Çekim Modeli}

Çekim Modeli, ülke çiftleri arasındaki karşılıklı ticaret akışını analiz etmek için kullanılan basit bir ampirik modeldir (Deardorff, 1998: 7-8). Uluslararası ticaret alanında kullanılan model, fizikte Newton'un 1687 yılında doğa bilimleri yazınında önerdiği “Evrensel Kütle Çekim Yasası”nın işlevine benzemektedir. Model, ülke çifti arasındaki ticaret akışını, ekonomik "kütleleri" (milli gelir) ile orantılı ve aralarındaki mesafeyle ters orantılı olarak açıklamaktadır (Dinh, Nguyen \& Cuong, 2011: 3-4).

Hollandalı ekonomist Jan Tinbergen aynı yasayı uluslararası ticaret akımlarını analiz etmek için 1962 yılında ekonomi alanına uyarlamıştır. Uluslararası iktisat alanına uyarladığı modelin formülasyonu aşağıdaki gibidir (Batra, 2006: 328);

$$
\text { Ticaret }_{i j}=\alpha \frac{{\text { GSYI } H_{\mathrm{i}} G S Y \dot{I}_{J}}_{J}}{\text { Mesafe }_{i j}}
$$

Denklemde yer alan değişkenler;

- Ticaret $_{i j}$ : i ve j ülkeleri arasında gerçekleşen ticaretin değerini,

- $G S Y \dot{I} H_{\mathrm{I}}$ : i ülkesinin milli hasılası,

- $G S Y \dot{I} H_{J}:$ j ülkesinin milli hasılası,

- Mesafe $e_{i j}$ : i ve j ülkeleri arsındaki uzaklığı, 
- $\alpha$ : model sabiti olarak tanımlanır.

Denklem (1)'e göre diş ticaret, ülkelerin GSYH'si ve ülkeler arasındaki coğrafi uzaklık (mesafe) değişkenleri ile açıklanmaktadır. Tinbergen'in kullandığı modele göre ülkeler arasında gerçekleşen ticaret akışını etkileyen pek çok faktör bulunmasına rağmen hiçbiri aşağıda yer alan üç değişken kadar etkili değildir. Bu üç değişken (Tinbergen, 1962: 263);

- Ülkenin ihraç kapasitesinin, ekonomik büyüklüğüne bağlı olması,

- Ülkenin gerçekleştirdiği ihraç düzeyinin, ithalatçı ülkenin ekonomik büyüklüğüne bağlı olması,

- Ulaştırma maliyetleri nedeniyle ticaret hacminin olumsuz etkilenmesidir.

Denklem (1)'in logaritması alınarak, doğrusal formu ve modele karşılık gelen tahmin edilebilir denklemin gösterimi aşağıdaki gibidir (Tinbergen, 1962: 265);

$$
\log \left(\text { Ticaret }_{i j}\right): \beta_{0}+\beta_{1} \log \left(G S Y \dot{\mathrm{I}} H_{\dot{\mathrm{I}}} \cdot G S Y \dot{\mathrm{I}} H_{J}\right)+\beta_{2} \log \left(\text { Mesafe }_{i j}\right)+e_{i j}
$$

Denklem (2);

- $\beta_{0}, \beta_{1}, \beta_{2}$ tahmin edilecek parametreleri,

- $e_{i j}$ hata terimini temsil etmektedir. Hata terimi, ticaret akışlarında tesadüfi faktörlerin etkilerin ölçmektedir.

Denklem (2), ikili ticaretin gelirin pozitif ve mesafenin negatif fonksiyonu olduğu tahmin edilen temel ağırlık model denklemidir (Deardroff, 1998: 9). Denkleme göre iki ülke arasındaki ticaret hacmi, ülkelerin büyüklükleriyle artan aralarındaki uzaklığa göre ise azalan bir fonksiyona dayanmaktadır (Karagöz, 2008: 152).

Ticaret teorisyenleri tarafından Çekim Modelinin, Eksik Rekabet ve Hecksher-Ohlin Modeline dayanan ticaret teorileriyle tutarlı olduğu bulunmuştur. Helpman (1987), mesafe değişkenin ticaret akışları ve ülke büyüklüğü arasında orantılı bir ilişkide pek bir rol içermediğini belirtmiştir. Ancak mesafe değişkeninin açıklayıcı bir değişken olarak modele eklenmesinde önemli birçok neden yer almaktadır. Bu nedenler arasında (Batra, 2006: 329);

- Mesafenin, ulaşım maliyetleri için bir gösterge olması,

- Mesafenin, taşıma sırasında geçen sürenin bir göstergesi ve bozulabilen ürünler için bozulmadan hayatta kalma olasılığı transit zamanın azalan bir fonksiyonu olmas1,

- Senkronizasyon maliyetleri: fabrikalar birden fazla girişi birleştirdiğinde, darboğazların ortaya çıkmasını önlemek için zamanlamaları senkronize edilmelidir. Senkronizasyon maliyetleri için bir gösterge olan uzaklığın, senkronizasyon maliyetleri arttıkça artması, 
- İşlem maliyetleri: mesafe, ticaret firsatlarını arama maliyetleri ve potansiyel ticaret ortakları arasında güven tesis etme ile ilişkili bulunması ve işlem maliyetleri için yaklaşık bir gösterge niteliğinde olması,

- Kültürel mesafe: daha büyük coğrafi mesafenin daha büyük kültürel farklılıklarla ilişkilendirilebilmesidir. Kültürel farklılıkların ise iletişimi engelleme, müzakere tarzlarında çatışmalara neden olarak ticareti kısıtlamasıdır.

Eksik Rekabet ve Hecksher-Ohlin Modeline dayanan ticaret teorileri Çekim Modelinin temel değişkenlerinin -gelir ve mesafe-modele dahil edilmesini desteklemektedir (Batra, 2006: 330). Basit-İlkesel Çekim Modelinin genişletilmiş hali Tinbergen tarafından 1962 yılında yayımlanan çalışmanın ikinci bölümünde ortaya çıkmıştır. Bu çalışmada Tinbergen, 1958 yılı verilerini kullanarak, 18 ülke için modeli test etmiştir. Çalışmanın ikinci aşamasında modele, ülkeler arasındaki karşılıklı dış ticareti, Çekim Modelinde yer alan değişkenlerin yanında politik ya da yarı ekonomik değişkenlerin sonucu etkileyip etkilemediğini görebilmek adına kukla değişkenler eklenmiştir. Böylelikle modele eklenilen kukla değişkenlerle ilkesel model genişletilmiştir (Dinçer, 2014: 6-7). Bunun dişında birçok çalışma coğrafi faktörler, tarihsel ve kültürel bağlar, genel ticaret politikası ve döviz kuru riski gibi faktörlerin etkilerini test etmek amacıyla ilave değişkenler kullanmış ve modeli genişletmişlerdir (Batra, 2006: 330).

Literatürde Basit/Ilkesel olarak geçen modelin kuramsal altyapısında eksiklikler ve yetersizlikler bulunmasıyla beraber genel olarak 1970'li yıllardan sonra kuramı geliştirmeye yönelik çalışmalar yapılmıştır. İlk olarak modelin ekonometrik özelliklerini geliştiren Mátyás (1997; 1998), Chen ve Wall (1999), Breuss ve Egger (1999) ve Egger (2000) yer almaktadır. Daha sonra analizde dikkate alınan açıklayıcı değişkenlerin iyileştirilmesine ve yeni değişkenlerin eklenmesine katkıda bulunarak akademik literatürde basit model kavramının yanı sıra genişletilmiş Çekim Modeli olarak da kullanıldığı çalışmalar arasında Wei, (1996), Soloaga ve Winters (1999), Limao ve Venables (1999), Bougheas et al. (1999), Anderson (1979), Bergstrand (1985;1989), Helpman ve Krugman (1985), Helpman (1987), Deadorff (1995;1998), Evenett ve Keller (1998) yer almaktadır (Zarzoso \& Lehman, 2003: 295).

\section{Literatür Taraması}

Çekim Modeli ile ilgili yazılmış birçok çalışmanın mevcut olması ve modelin son 40 yıldır yaygın olarak kullanılması sebebiyle bu bölümde, uluslararası ticaret alanında yayımlanmış bazı çalışmalar ele alınmıştır. Breuss ve Egger (1999), Filippini ve Molini (2003) ve Baldwin ve Taglioni (2011)'de bölgeler veya ülkeler arasındaki ticaret ilişkisi analiz edilirken Aitken (1973), Thursby ve Thursby (1987), Eichengreen ve Irwin (1998), Endoh (1999), Wall (1999) ve Nitsch (2006)'de ticaret akışlarında döviz kurunun, Linder hipotezinin, tarihsel faktörlerin, ticari korumacı politikaların, ekonomik kuruluşlar ve birlikler gibi açıklayıcı değişkenlerin etkileri test edilmiştir. 
Tekin, M. \& F. Merdivenci (2022), “E7 Ülkeleri ile Türkiye Arasındaki Dış Ticaretin Panel Veri Analizi: Çekim Modeli Yaklaşımı”, Sosyoekonomi, 30(51), 407-426.

Tabloda Türkiye'nin dış ticaretinin çekim modeli ile analiz edildiği çalışmalar da mevcuttur. Bunlar arasında Tatlıcı ve Kızıltan (2011) ve Yaşar (2011) Gümrük Birliğinin Türkiye'nin ticaret akışına ve ihracatına etkisini analiz etmiş ve Ata (2012), Sorhun (2013) ve Işık (2016) Türkiye'nin dış ticaret potansiyelini Çekim Modeli ile incelemiştir.

Tablo: 2

Çekim Modeli ile Uluslararası Ticaret Analizi Yapan Ampirik Çalışmalar

\begin{tabular}{|c|c|c|c|c|c|}
\hline Yil & Yazar & Amaç & Veriler & $\begin{array}{c}\text { Bağımlı } \\
\text { Değișkenler }\end{array}$ & $\begin{array}{c}\text { Açıklayıcı } \\
\text { Değișkenler }\end{array}$ \\
\hline 1973 & Aitken & $\begin{array}{l}\text { Avrupa ticaret ilişkilerini } \\
\text { şekillendiren kuvvetlerin } \\
\text { incelenmesi }\end{array}$ & $\begin{array}{l}\text { En Küçük Kareler Regresyon } \\
\text { Yöntemi, AET ve EFTA, } \\
\text { 1951-1967 }\end{array}$ & $\begin{array}{l}\text { Ticaret } \\
\text { Akışı }\end{array}$ & $\begin{array}{l}\text { İhracat, ithalat, nominal GSYH, nüfus } \\
\text { ve fiziki uzaklık, kukla değişken } \\
\text { olarak ise komşu ülkeler ve AET ya } \\
\text { da EFTA üyeliği }\end{array}$ \\
\hline 1987 & $\begin{array}{l}\text { Thursby \& } \\
\text { Thursby }\end{array}$ & $\begin{array}{l}\text { İkili ticaret akımında döviz kuru } \\
\text { değişkenliği ve Linder hipotezi } \\
\text { etkisini analizi }\end{array}$ & $\begin{array}{l}\text { Kesit Verisi Regresyon } \\
\text { Analizi, } 17 \text { Ülke, 1974-1982 }\end{array}$ & $\begin{array}{c}\text { Ticaret } \\
\text { Akışı }\end{array}$ & $\begin{array}{l}\text { Linder terimi katsayısı, döviz kuru } \\
\text { esnekliği }\end{array}$ \\
\hline 1998 & $\begin{array}{l}\text { Eichengreen } \\
\text { \& Irwin }\end{array}$ & $\begin{array}{l}\text { Ticaret akışlarında tarihsel } \\
\text { unsurların etkisinin incelenmesi }\end{array}$ & $\begin{array}{l}\text { En Küçük Kareler Regresyon } \\
\text { Yöntemi, AB Üyeleri, 1928, } \\
\text { 1938, 1949, } 1954 \text { ve } 1964 \\
\text { Yıllarına İlişkin Veriler } \\
\end{array}$ & $\begin{array}{c}\text { Ticaret } \\
\text { Akışı }\end{array}$ & $\begin{array}{l}\text { GSMH, kişi başına düşen GSMH, } \\
\text { coğrafi uzaklık ve kukla değişken } \\
\text { olarak sinır komşuluğu, GATT ve } \\
\text { AET üyeliği }\end{array}$ \\
\hline 1999 & Endoh & $\begin{array}{l}\text { AET, Latin Amerika Serbest } \\
\text { Ticaret Bölgesi (LAFTA) ve } \\
\text { Karşılıklı Ekonomik Yardım } \\
\text { Konseyinin (CMEA) bölgesel } \\
\text { oluşumunda ticareti özendirici ve } \\
\text { caydırıcı etkilerinin analizi }\end{array}$ & $\begin{array}{l}\text { Panel Veri, EEC, LAFTA ve } \\
\text { CMEA Üyeleri, 1960-1994 }\end{array}$ & İhracat & $\begin{array}{l}\text { GSYH, mesafe, nüfus, AET, LAFTA } \\
\text { ve CMEA'nın etkileri, ortak sınır ve } \\
\text { ortak dil }\end{array}$ \\
\hline 1999 & Wall & $\begin{array}{l}\text { Ticari korumacı politikaların ABD } \\
\text { ticareti üzerindeki etkilerine ilişkin } \\
\text { yeni tahminler elde etmek, }\end{array}$ & $\begin{array}{l}\text { Panel Veri, ABD ve } \\
85 \text { Ticaret Ortağı Ülke, } \\
\text { 1994-1996 }\end{array}$ & $\begin{array}{l}\text { Ticaret } \\
\text { Akışı }\end{array}$ & $\begin{array}{l}\text { GSYH, mesafe, Heritage Foundation } \\
\text { Ticaret Özgürlüğü Endeksi ticaret } \\
\text { politikası bileşenleri, NAFTA üyeliği } \\
\text { kukla değişkeni }\end{array}$ \\
\hline 2000 & $\begin{array}{l}\text { Kimura } \\
\text { \& Lee }\end{array}$ & $\begin{array}{l}\text { Çeşitli faktörlerin hizmet ticaretine } \\
\text { etkisinin incelenmesi }\end{array}$ & $\begin{array}{l}\text { Panel Veri,10 OECD Üyesi, } \\
\text { 1999-2000 }\end{array}$ & $\begin{array}{c}\text { Ticaret } \\
\text { Akışı }\end{array}$ & $\begin{array}{l}\text { GSYH, nüfus, coğrafi uzaklık, kişi } \\
\text { başına GSYH ve Dünya Ekonomik } \\
\text { Özgürlük Endeksi değerleri, Bölgesel } \\
\text { Ticaret Anlaşması ile ortak sınır ve } \\
\text { ortak dil kukla değişkeni }\end{array}$ \\
\hline 2002 & Egger & $\begin{array}{l}\text { Çekim Modelinin ekonometrik } \\
\text { görünümü }\end{array}$ & $\begin{array}{l}\text { Panel Veri, OECD ve } \\
\text { 10 Orta ve Doğu Avrupa } \\
\text { Ülkesi (CEECs), } \\
\text { 1986-1997 }\end{array}$ & İhracat & $\begin{array}{l}\text { GSYH, kişi başına düşen GSYH, } \\
\text { fiziki ülke büyüklükleri, ülkelerin } \\
\text { göreli faktör donatımlarındaki } \\
\text { farkları, reel döviz kuru değişkenleri, } \\
\text { coğrafi uzaklık değerleri, ortak sınır } \\
\text { ile ortak dil }\end{array}$ \\
\hline 2003 & $\begin{array}{l}\text { Filippini } \\
\text { \& Molini }\end{array}$ & $\begin{array}{l}\text { Doğu Asya ülkelerinin ticaret } \\
\text { akışlarının analizi }\end{array}$ & $\begin{array}{l}\text { Panel Veri, } 11 \text { AB Üyesi, } \\
\text { ABD, } \\
\text { Japonya, Çin, } 6 \text { Asya ve } 6 \\
\text { Latin } \\
\text { Amerika Ülkesi, 1970-2000 }\end{array}$ & İhracat & $\begin{array}{l}\text { Geçmiş ihracat, nüfus, GSYH, coğrafi } \\
\text { uzaklık ve teknolojik uzaklık } \\
\text { değişkenleri }\end{array}$ \\
\hline 2003 & $\begin{array}{l}\text { Anderson } \\
\text { \& Wincoop }\end{array}$ & $\begin{array}{l}\text { Kanada, ABD ve } 30 \text { diğer } \\
\text { sanayileşmiş ülkeye ilişkin } \\
\text { kapsamlı bir analizi }\end{array}$ & $\begin{array}{l}\text { Doğrusal Olmayan En Küçük } \\
\text { Kareler Yöntemi, Kanada, } \\
\text { ABD ve } 30 \text { Sanayileşmiş } \\
\text { Ülke, } 1993 \text { Y1lı Verileri } \\
\end{array}$ & $\begin{array}{l}\text { İhracat/ } \\
\text { Ticaret } \\
\text { Akışı }\end{array}$ & $\begin{array}{l}\text { İhracat, ithalat, coğrafi uzaklık, } \\
\text { GSYH ve nüfus değişkenleri, sınır } \\
\text { etkileri }\end{array}$ \\
\hline 2003 & $\begin{array}{l}\text { Baltagi, } \\
\text { Egger \& } \\
\text { Pfaffermayr }\end{array}$ & $\begin{array}{l}\text { EU15, ABD ve Japonya'nın 1986- } \\
1997 \text { dönemleri arasında } 57 \text { ticaret } \\
\text { ortağı ile gerçekleştirdikleri } \\
\text { ticaretin analizi }\end{array}$ & $\begin{array}{l}\text { Panel Veri, AB15, ABD, } \\
\text { Japonya ve } 57 \text { Ticaret Ortağ1 } \\
\text { Ülke, 1986-1997 }\end{array}$ & $\begin{array}{l}\text { Ticaret } \\
\text { Akışı }\end{array}$ & $\begin{array}{l}\text { Genel ikili boyutun (LGDT), ikili } \\
\text { boyuttaki benzerliğin (LSIM), bağıl } \\
\text { faktör donanımlarındaki (LRFAC) } \\
\text { farklılığın ve CIF ve FOB arasındaki } \\
\text { farkla ölçülen nakliye maliyetlerinin } \\
\text { (LTC) etkisi }\end{array}$ \\
\hline 2005 & $\begin{array}{l}\text { Brun, Carrère, } \\
\text { Guillaumont } \\
\text { \& De Melo }\end{array}$ & $\begin{array}{l}130 \text { ülkenin, 1962-96 yılları } \\
\text { arasındaki ticaret akımlarını } \\
\text { analizi }\end{array}$ & $\begin{array}{l}\text { Panel Veri, } 130 \text { Ülke, } \\
\text { 1962-1996 }\end{array}$ & $\begin{array}{l}\text { Ticaret } \\
\text { Akışı }\end{array}$ & $\begin{array}{l}\text { GSYH, nüfus, mesafe, altyapı ve } \\
\text { petrol fiyatları endeksi, temel malların } \\
\text { toplam dışsatımdaki payı ve reel } \\
\text { döviz kuru değişkenleri ve herhangi } \\
\text { bir gümrük birliğine üyelik değişkeni }\end{array}$ \\
\hline 2006 & Batra & $\begin{array}{l}\text { Hindistan ticaret potansiyeli } \\
\text { analizi }\end{array}$ & $\begin{array}{l}\text { Kesit Veri Analizi, } 146 \text { Ülke, } \\
2000 \text { Y1lı Verileri }\end{array}$ & $\begin{array}{l}\text { Ticaret } \\
\text { Akışı }\end{array}$ & $\begin{array}{l}\text { GSMH, satın alma gücü paritesine } \\
\text { göre GSMH, kişi başına gelir, nüfus, } \\
\text { coğrafi uzaklık, ticaret hacmi ve kukla } \\
\text { değișkenler }\end{array}$ \\
\hline
\end{tabular}


Tekin, M. \& F. Merdivenci (2022), "E7 Ülkeleri ile Türkiye Arasındaki Dış Ticaretin Panel Veri Analizi: Çekim Modeli Yaklaşımı”, Sosyoekonomi, 30(51), 407-426.

\begin{tabular}{|c|c|c|c|c|c|}
\hline 2006 & Carrère & $\begin{array}{l}\text { Bölgesel ticaret anlaşmalarının } \\
\text { etkilerinin araştırılması }\end{array}$ & $\begin{array}{l}\text { Panel Veri Analizi, } \\
130 \text { Ülke, 1962-1996 }\end{array}$ & İhracat & $\begin{array}{l}\text { GSYH, kişi başına GSYH, nüfus, } \\
\text { mesafe, paylaşılan sınırlar, karayla } \\
\text { çevrili ülke, altyapı düzeyi, döviz } \\
\text { kurları, Serbest Ticaret Anlaşması } \\
\text { kukla değişkeni }\end{array}$ \\
\hline 2006 & Nitsch & $\begin{array}{l}\text { G7/G8 üyeliğinin ülkelerin ticaret } \\
\text { akımına etkisinin analizi }\end{array}$ & 175 Ülke, 1948-1999 & $\begin{array}{c}\text { Ticaret } \\
\text { Akışı }\end{array}$ & $\begin{array}{l}\text { GSYH, Kişi başı GSYH, mesafe, } \\
\text { G7/G8 üyeliği, ortak dil, ortak sınır, } \\
\text { ortak para birimi, GATT/Dünya } \\
\text { Ticaret Örgütü üyeliği, IMF üyeliği, } \\
\text { OECD üyeliği, Bölgesel Serbest } \\
\text { Ticaret Anlaşması üyeliği, Kolonyal } \\
\text { bağlantı }\end{array}$ \\
\hline 2008 & $\begin{array}{l}\text { Helpman, } \\
\text { Melitz \& } \\
\text { Rubinstein }\end{array}$ & $\begin{array}{l}\text { Karşılıklı gerçekleşen ticaret } \\
\text { akımının Çekim Modeli ile analizi }\end{array}$ & $\begin{array}{l}\text { Panel Veri,161 Ülke, } \\
\text { 1970-1997 }\end{array}$ & $\begin{array}{c}\text { Ticaret } \\
\text { Akışı }\end{array}$ & $\begin{array}{l}\text { Dışsatım, reel GSYH, kişi başına } \\
\text { düşen reel GSYH, coğrafi uzaklık } \\
\text { değişkenleri ile GATT/ DTÖ üyeliği, } \\
\text { kolonyal geçmiş, ortak dil ve bir } \\
\text { parasal birliğin üyesi olma kukla } \\
\text { değişkenleri }\end{array}$ \\
\hline 2011 & $\begin{array}{l}\text { Baldwin \& } \\
\text { Taglioni }\end{array}$ & $\begin{array}{l}\text { Uluslararası tedarik zincirlerinin } \\
\text { ve parça ticaretinin standart Çekim } \\
\text { Modeli ile incelenmesi }\end{array}$ & $\begin{array}{l}\text { Panel Veri, } 187 \text { Ülke, } \\
\text { 2000-2007 }\end{array}$ & $\begin{array}{l}\text { Ticaret } \\
\text { Akış1 }\end{array}$ & $\begin{array}{l}\text { Toplam ithalat, toplam ihracat, ara } \\
\text { mal ithalat1, ara mal ihracat1, tüketim } \\
\text { mal ihracat1 ve ithalatı verileri }\end{array}$ \\
\hline 2016 & $\begin{array}{l}\text { Rasoulinezhad } \\
\text { \& Seong }\end{array}$ & $\begin{array}{l}\text { Güney Kore'nin } 13 \text { OPEC üyesi } \\
\text { ülke ile gerçekleştirdiği dış ticareti } \\
\text { Çekim Modeli yaklaşımı ile } \\
\text { analizi }\end{array}$ & $\begin{array}{l}\text { Panel Veri, Güney Kore, } \\
13 \text { OPEC Üyesi, 1980-2014 }\end{array}$ & $\begin{array}{c}\text { Ticaret } \\
\text { Akış1 }\end{array}$ & $\begin{array}{l}\text { GSYH, kişi başı GSYH, mesafe, } \\
\text { Dünya Ticaret Örgütü üyeliği, ticari } \\
\text { açıklık düzeyi, döviz kuru ve Linder }\end{array}$ \\
\hline 2011 & $\begin{array}{l}\text { Tatlicı \& } \\
\text { Kiziltan }\end{array}$ & $\begin{array}{l}\text { Çekim Modelinin Türk ihracatını } \\
\text { açıklamada uygun olup olmadığı } \\
\text { analizi }\end{array}$ & $\begin{array}{l}\text { Panel Veri,46 Ülke, } \\
\text { 1994-2007 }\end{array}$ & İhracat & $\begin{array}{l}\text { GSYH, nüfusları, ülkelerin } \\
\text { baškentlerinin Ankara'ya uzaklıkları, } \\
\text { gümrük birliği üyeliği ve ortak sınır }\end{array}$ \\
\hline 2011 & Yaşar & $\begin{array}{l}\text { Türkiye'nin ihracatına Gümrük } \\
\text { Birliği üyeliğinin etkisinin analizi }\end{array}$ & $\begin{array}{l}\text { Panel Veri, Türkiye-AB } \\
\text { Üyeleri, 1999-2009 }\end{array}$ & İhracat & GSYH, mesafe, nüfus \\
\hline 2012 & Ata & $\begin{array}{l}\text { Türkiye'nin ticaret potansiyelini } \\
\text { Çekim Modeliyle incelenmesi }\end{array}$ & $\begin{array}{l}\text { Panel Veri, } 68 \text { Ülke (OECD } \\
\text { Üyeleri, AB-27 ve Euro } \\
\text { Bölgesi), 1980-2009 }\end{array}$ & İhracat & $\begin{array}{l}\text { GSYH, mesafe, ortak dil kullanılması, } \\
\text { ülke komşuluğu, kolonyal bağ, ülke } \\
\text { para birimleri arasındaki reel kur } \\
\text { endeksi, ülkelerinin kaç tanesinin kara } \\
\text { ile çevrili olduğu }\end{array}$ \\
\hline 2012 & Baytar & $\begin{array}{l}\text { Türkiye ve BRIC ülkeleri } \\
\text { arasındaki ticaret hacminin analizi }\end{array}$ & $\begin{array}{l}\text { Panel Veri, Türkiye- BRIC, } \\
\text { 2001-2010 }\end{array}$ & $\begin{array}{l}\text { Ticaret } \\
\text { Hacmi }\end{array}$ & $\begin{array}{l}\text { GSYH, mesafe, nüfus, ithalat, ihracat, } \\
\text { Ticaret Bağlllık Endeksi, İthalat } \\
\text { Nüfus Endeksi ve İhracat Eğilim } \\
\text { Endeksi }\end{array}$ \\
\hline 2013 & Sorhun & $\begin{array}{l}\text { Türkiye'nin potansiyel dış } \\
\text { ticaretinin belirlemek ve } \\
\text { potansiyelin ne kadarının } \\
\text { kullanıldığının analizi }\end{array}$ & $\begin{array}{l}\text { SPSS, Türkiye-AB-15, AB’ye } \\
\text { Son İki Genişlemede Dâhil } \\
\text { Olan Ülkeler (AB-Yeni } \\
\text { Üyeler), Akdeniz, Ortadoğu, } \\
\text { Afrika, Karadeniz Ekonomik } \\
\text { İsbirliği (KEI) ve Orta Asya } \\
\text { Ülkeleri, 1992-2012 }\end{array}$ & $\begin{array}{l}\text { İthalat/ } \\
\text { İhracat }\end{array}$ & $\begin{array}{l}\text { GSYH, mesafe, ortak sınır, AB-15 } \\
\text { üyeliği, AB-Yeni üyeleri Akdeniz } \\
\text { Ülkeleri, Afrika ülkeleri KEI ülkeleri, } \\
\text { Orta Asya ülkeleri, Arap Baharı ve } \\
\text { Küresel kriz kukla değişkenleri }\end{array}$ \\
\hline 2016 & Işsk & $\begin{array}{l}\text { Türkiye ve Şanghay İşbirliği } \\
\text { Örgütü (Şiö) arasında gerçekleşen } \\
\text { dış ticaret akımı Çekim Modeli } \\
\text { kapsamında analizi }\end{array}$ & $\begin{array}{l}\text { Panel Veri, Türkiye ve } \\
\text { Şangay İşbirliği Örgütü (Şiö) } \\
\text { 2004-2014 }\end{array}$ & $\begin{array}{c}\text { Ticaret } \\
\text { Akış1 }\end{array}$ & $\begin{array}{l}\text { GSYH, nüfus, mesafeyi, küresel kriz } \\
\text { kukla değişkeni }\end{array}$ \\
\hline
\end{tabular}

Ülkeler arasındaki ticaret akışını Çekim Modeli kullanarak analiz eden ve ticaret akışlarında döviz kuru, Linder hipotezi ve tarihsel faktörler gibi kukla değişkenler kullanan Aitken (1973), Thursby ve Thursby (1987), Eichengreen ve Irwin (1998), Wall (1999) ve Nitsch (2006) Çekim Modeli varsayımını destekler sonuçlar elde etmişlerdir. Endoh (1999), Egger (2002), Filippini ve Molini (2003), Carrère (2006) ve Baldwin ve Taglioni (2011)'de bölgeler veya ülkeler arasındaki ticaret ilişkisini analiz etmek için bağımlı değişken olarak ihracat verileri ele alınmış ve çalışma sonucunda Çekim Modeli varsayımı desteklenmiştir. Türkiye'nin ticaret akışını ve dış ticaret potansiyellerini Çekim Modeli kullanarak inceleyen Tatlıcı ve Kızıltan (2011), Yaşar (2011), Ata (2012), Sorhun (2013) ve Işık (2016) da benzer sonuçlar elde etmiştir. 
Ülke çiftleri arasındaki karşılıklı ticaret akışını analiz etmek için kullanılan basit ampirik model olan Çekim Modeli (Deardorff, 1998: 7-8), geliştirilmeye yönelik yapılan çalışmalar ve eklenen açıklayıcı değişkenlerle beraber yaygın olarak kullanılmıştır. Literatürde gümrük birliğine, serbest ticaret anlaşmasına, uluslararası resmi ekonomik kurum ve kuruluşlarına üyelik ve ortak para birimini paylaşmak, aynı ulusun parçası olmak, geçmişte veya şimdi kolonyal bir bağlantının olması bölgeler arasındaki ticaret akışlarını etkileyebilecek faktörler arasında sayılmaktadır. Bunların potansiyel etkileri de çeşitli kukla değişkenler aracılığıyla yapılan çalışmalarda test edilmektedir (Kepaptsoglu et al., 2010: 9).

$\mathrm{Bu}$ çalışma uygulama örnekleri ve zaman aralığı (parametreler) bağlamında literatürde yer alan çalışmalardan farklılık göstermektedir. Türkiye'nin E7 ülkeleri arasında yer alan Çin, Hindistan, Rusya, Brezilya, Meksika ve Endonezya ile 2000-2018 yılları arası gerçekleştirdiği dış ticaret hacminin analiz edilmesi amaçlanana bu çalışmada, bağımlı değişken olarak ticaret hacmi yer alırken bağımsız değişken olarak da Türkiye'nin ve E7 ülkelerinin GSYH'si, nüfusu, Linder değişkeni ve ülke başkentleri arasındaki mesafenin anlamlılığı yer alacaktır.

Çekim Modelinin seçilmesi aşağıda verilen maddelerin önemiyle belirlenmiştir:

- Uluslararası ticaretin modellenmesi ve analiz edilmesi durumlarında son yıllarda yaygın olarak kullanılması,

- Uzun zamandır ekonomideki başarılı ampirik modeller arasında yer alması,

- Ekonomideki istikrarlı ilişkileri açıklayabilmesi,

- Uluslararası ticaret akışlarını araştırmak ve uluslararası ticaretin kapsamını açıklanabilmesi için birden fazla değişkenin kullanılmasına ve dikkate alınabilmesine izin vermesi,

- Bölgesel ticaret modellerini açıklamak için başarılı modellerden biri olması,

- Alternatif uluslararası ticaret kuramlarıyla uyum gösterebilmesidir.

\section{Ampirik Çerçeve}

\subsection{Veri Seti ve Değişkenler}

Bu çalışmada Türkiye ve E7 ülkeleri arasındaki dış ticaret hacmi, Çekim Modeli yaklaşımıyla panel veri yöntemi kullanılarak analiz edilmiştir. 2000-2018 dönemi yıllık verilerinin alındığı bu çalışmada 6 (N) ülke 19 yıl (T) olmak üzere 114 gözlem, dengeli panel verileri ile analiz edilmiştir. Dış ticaret hacminin bağımlı değişken seçildiği modellerde ilk önce Basit/İlkesel Çekim Modeli ile analiz yapılmış ve bu doğrultuda açıklayıcı değişkenler GSYH ve mesafe olmuştur. Daha sonra genişletilmiş Çekim Modeli oluşturulmuş ve kurulan diğer modellere Linder ve nüfus değişkeni eklenmiştir. Çalışmada kullanılan veriler ile açıklamalarına ve veri kaynaklarına ilişkin bilgiler Tablo 3 'te özetlenmiştir. Serileri olası değişen varyans ve kısmen de otokorelasyona karşı koruyabilmek için tüm değişkenlerin doğal logaritmik dönüşümü yapılmıştır. 
Tablo: 3

Kullanılan Değişkenler, Değişken Tanımları ve Kaynakları

\begin{tabular}{|c|c|c|}
\hline Değişkenler & Kisaltma & Veri Tanımları ve Veri Kaynağı \\
\hline $\begin{array}{l}\text { Diş Ticaret } \\
\text { Hacmi }\end{array}$ & LogDTijt & $\begin{array}{l}\text {-t zamanında i ülkesinden j ülkesine yapılan ihracat ve ithalatın toplamından oluşmaktadır. } \\
\text { Kaynak: Türkiye İstatistik Kurumu (TÜIK) }\end{array}$ \\
\hline GSYH & 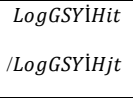 & $\begin{array}{l}\text {-t zamanında i ülkesinin yani ihracatçı ülkenin GSYH'si } \\
\text { - t zamanında j ülkesinin yani ithalatçı ülkenin GSYH'si } \\
\text { Kaynak: Dünya Bankası (ABD doları olarak alınmıştır). }\end{array}$ \\
\hline Mesafe & LogMesafeij & $\begin{array}{l}\text {-i ülkesi ile j ülkesi arasındaki coğrafi uzaklığı göstermektedir. } \\
\text { Kaynak: Ülkeler arasındaki mesafe rakamları http://tr.mesafe hesaplama.himmera.com/ara/ adresinden elde } \\
\text { edilmiştir. }\end{array}$ \\
\hline Linder Hipotezi & Linder $_{i j t}$ & -Karşılıklı ticaret ilişkisinde bulunan ülkelerin kişi başına düşen gelirleri arasındaki fark olarak belirtilmektedir. \\
\hline Nüfus & $\begin{array}{l}\text { LogNufusit } \\
\text { LogNufusjt }\end{array}$ & $\begin{array}{l}\text {-t zamanında i ülkesinin yani ihracatçı ülkenin toplam nüfusu. } \\
\text {-t zamanında j ülkesinin yani ithalatçı ülkenin toplam nüfusu. } \\
\text { Kaynak: Dünya Bankası }\end{array}$ \\
\hline
\end{tabular}

\subsection{Panel Veri Analizi}

Çekim Modeli uygulamalarında ekonometrik yöntem olarak kullanılan panel veri analizi, tahmin edilmek istenen modelde bireyler, ülkeler, hane halkları, firmalar ve şehirler gibi birimlerin yer aldığ 1 yatay kesit verilerinin zaman serileri içinde analiz edilmesiyle oluşan havuzlandırılmış veriler olarak tanımlanmaktadır (Baltagi, 2005: 1). Ekonometrik modelde, yatay kesit ve zaman serisinin birlikte kullanılması birimler arasında ve zaman içerisinde meydana gelen farklılıkları beraber incelemesine imkân sağlamaktadır (Dinçer, 2013: 112).

Panel veri modelinin standart fonksiyonel gösterilimi aşağıdaki gibidir (Hsiao, 2005: 149). Burada;

$$
\begin{aligned}
& Y_{i t=} a+\beta_{1 i t} X_{1 i t}+\beta_{2 i t} X_{2 i t}+\cdots \ldots \ldots+\beta_{k i t} X_{k i t}+u_{i t} \\
& \mathrm{i}=1,2, \ldots, \mathrm{N}(\text { yatay kesit birim sayısı "N" olarak gösterilmekte), } \\
& \mathrm{t}=1,2, \ldots, \mathrm{T} \text { (dönem sayısı “T” olarak gösterilmekte), } \\
& \text { Y: Bağımlı değişken, } \\
& \mathrm{X}: \text { Bağımsız değişken, } \\
& \alpha: \text { Sabit katsayı, } \\
& \beta: \text { Bağımsız değişkenlerin katsayıları, } \\
& \text { k: Bağımsız değişken sayısı, } \\
& \text { u: hata terimidir. }
\end{aligned}
$$

$\mathrm{Bu}$ çalışmanın teorik modeli ise Çekim Modeli doğrusal regresyon değişkenleri ve çalışmanın amacı doğrultusunda eklenmiş açıklayıcı değişkenler ile oluşturulmuştur. Modellerin ekonometrik yaklaşımla tam logaritmik formu:

\section{Model 1}

$$
\operatorname{LogDT}_{i j t}=\beta_{0}+\beta_{1} \log G S Y \dot{\mathrm{I}} H_{i t}+\beta_{2} \log G S Y \dot{\mathrm{I}} H_{j t}+\beta_{3} \log M e s a f e_{i j}+\epsilon_{i j t}
$$


Tekin, M. \& F. Merdivenci (2022), "E7 Ülkeleri ile Türkiye Arasındaki Dış Ticaretin Panel Veri Analizi: Çekim Modeli Yaklaşımı”, Sosyoekonomi, 30(51), 407-426.

\section{Model 2}

$$
\operatorname{LogDT}_{i j t}=\beta_{0}+\beta_{1} \log G S Y \dot{I} H_{i t}+\beta_{2} \log G S Y \dot{I} H_{j t}+\beta_{3} \log M e s a f e_{i j}+\beta_{4} \text { Linder }_{i j t}+\epsilon_{i j t}
$$

\section{Model 3}

$$
\begin{aligned}
& \operatorname{LogDT}_{i j t}=\beta_{0}+\beta_{1} \log G S Y \dot{I} H_{i t}+\beta_{2} \log G S Y \dot{I} H_{j t}+\beta_{3} \operatorname{logNufus} s_{i t}+\beta_{4} \operatorname{logNufus} s_{j t}+ \\
& \beta_{5} \operatorname{logMesafe} e_{i j}+\epsilon_{i j t}
\end{aligned}
$$

Çekim Modeli teorisi doğrultusunda dış ticaret hacminin, ülkelerin GSYH değişkenlerinin pozitif mesafe değişkenlerinin ise negatif bir fonksiyonu olması beklenmektedir. Diğer açıklayıcı değişkenlerden Linder'in iki ülke arasındaki mamul mal ticaretinin kişi başına gelirlerindeki farkla ters orantılı olması nedeniyle (Thursby ve Thursby, 1987: 488) Çekim Modeli analizi sonucunda, Linder değişkeni işaretinin negatif olması iki ülke arasındaki ticaret akışında Linder Hipotezini doğrular nitelikte olduğu anlamına gelmektedir (Dinçer, 2014: 15). Nüfus değişkeni için ise Oguledo ve Macphee (1994), ticaret yapan ülkelerin nüfus büyüklüklerinin ticaret akışları üzerinde olumsuz ve istatistiksel olarak anlamlı bir etkisinin olduğunu belirtmiştir.

\subsection{Panel Birim Kök Testi}

Panel veriler için birim kökün varllğı, yatay kesit bağımlılığı testleriyle kontrol edilmektedir. Durağanlık testlerinde, zaman $(T)$ ve yatay kesit $(N)$ boyutunun karşılaştırmalı büyüklüğüne göre farklı testler uygulanabilmektedir (Demiral vd., 2016: 95). Yatay kesit bağımlılı̆g testleri literatürde genel olarak 20-30 yılı aşan makro panellerde test edilmiştir. Yatay kesit bağımlılığı testini geliştiren Pesaran'ın da arasında yer aldığı Holly et al. (2010), zaman boyutu olarak 49 ABD eyaletinin 29 ylllık verilerini kullanarak eşbütünleşme ve yatay kesit bağımlılığını incelemiştir. Banerjee ve Carrion-i-Silvestre (2006), yatay kesit bağımlılı̆̆ 1 için $\mathrm{N}=40$ birim ve $\mathrm{T}=(50 ; 100 ; 250)$ olacak gözlemleri dikkate aldıklarını belirtmiştir. Benzer şekilde literatürde yer alan diğer çalışmalar arasında Westerlund (2005), Pesaran (2015) ve Bai ve Kao (2006) yer almaktadır. Bu çalışmanın boyutları; T = 19 ve N $=6$ şeklindedir. Boyut sayısının kısıtlı olması nedeniyle yatay kesit bağımlılığına bakılmamıştır.

Çekim Modellerinde kullanılan makroekonomik (GSYH ve ticaret) değişkenlerin genellikle durağan olmadığı varsayılır (Fidrmuc, 2009: 438). Ayrıca Panel veri modeli, zaman serisini içerdiği için de serilerin durağanlığı analiz edilmelidir. Bu sebeplerden dolayı panel veri analizlerinde öncelik olarak serilerin durağan olup olmadığı panel birim kök testleri aracılı̆̆ıyla tespit edilmelidir (Sevüktekin \& Nargeleçekenler, 2010: 313). Bu çalışmada panel veri analizinde yaygın kullanılan birinci kuşak panel birim kök testlerinden Levin, Lin ve Chu, Im Pesaran Shin, Fisher ADF kök testlerine yer verilmiştir. 


\subsection{Hausman Testi}

Panel veri analizinde, her bir birimde gözlenemeyen birim etkiler ortaya çıkabilmektedir. Birim etkiler, hata terimi değişkeni gibi varsayılıyorsa, rassal etkiler; bir yatay kesit gözlem için tahmin edilmiş bir değişken olarak varsayılıyorsa sabit etkiler yaklaşımı söz konusudur (Tatoğlu, 2018: 79). Panel veri analizde sabit etki ve rassal etki yaklaşımlar arasından modele uygun olan tahmin yönteminin seçimi önemlidir. Bu yaklaşımlar arasında seçimin yapılabilmesi için de Hausman Testi yaygın olarak kullanılmaktadır (Koy vd., 2019: 170).

Sabit ve rassal etki modelleri arasında bazı farklar vardır ve en önemlilerinden biri de birim etkilerin bağımsız değişkenlerle korelasyon halinde olup olmadığıdır. Korelasyonun olmaması durumunda rassal etki modelinin uygunluğu kabul edilmektedir. Tam tersi durumda ise sabit etkiler modelinin uygunluğu söz konusudur (Koy vd., 2019: 170). Çalışmada model seçimi için Hausman Test istatistiğinden yararlanılmış olup test sonucunda rassal etkiler modeli kullanılması uygun görülmüştür.

\section{Ampirik Bulgular}

Uygulamada ilk olarak değişkenler arasında sahte regresyon bulunmaması amacıyla değişkenlerin birim köke sahip olup olmadığı incelenmiştir. Uygulanacak olan birim kök testleri birinci kuşak panel birim kök testlerinden Levin, Lin ve Chu, Im Pesaran Shin ve Fisher ADF Chi-square kök testleridir. Birim kök test sonuçları istatistik ve prob değerleri açısından tablolaştırılmış ve sonuçları Tablo 4'te sunulmuştur.

Tablo: 4

\section{Birim Kök Test Sonuçları}

\begin{tabular}{|c|c|c|c|c|c|c|}
\hline \multirow{2}{*}{ Değişkenler } & \multicolumn{2}{|c|}{ Levin, Lin ve Chu } & \multicolumn{2}{|c|}{ Im, Pesaran ve Shin W-stat } & \multicolumn{2}{|c|}{ ADF- Fisher Chi-square } \\
\hline & Test ist. & p-değeri & Test ist. & p-değeri & Test ist & p-değeri \\
\hline$D_{\text {lş Ticaret Hacmi }}$ & -7.73999 & $0.0000^{*}$ & -4.00885 & $0.0000 *$ & 39.1732 & $0.0001^{*}$ \\
\hline GSYIHi & -10.7454 & $0.0000 *$ & -7.10318 & $0.0000^{*}$ & 66.6618 & $0.0000^{*}$ \\
\hline$G S Y I H j$ & -3.35447 & $0.0004 *$ & -0.84880 & 0.1980 & 13.4387 & 0.3380 \\
\hline Linder & -4.18345 & $0.0000 *$ & -2.64067 & $0.0041^{*}$ & 32.6366 & $0.0011^{*}$ \\
\hline Nüfusi & 2.58757 & 0.9952 & 5.66049 & 1.0000 & 0.12054 & 1.0000 \\
\hline Nüfusj & -2.29036 & $0.0110^{* * *}$ & -1.46507 & $0.0715^{* * * *}$ & 27.4621 & $0.0066^{*}$ \\
\hline
\end{tabular}

Not: *, **ve ***istatistikleri strasıyla $\% 1, \% 5$ ve \%10 düzeyinde anlaml olduğunu göstermektedir.

Birim kök testlerinde GSYIHi,Linder ve Nüfusj değişkenleri durağan olduğu görülmüştür. Diğer değişkenlerden GSYIHj değiş̧keni sadece Levin, Lin ve Chu testinde \% 1 anlamlılık düzeyine göre durağanken $N$ ü $f u s i$ değişkenin ise hiçbir kök testine göre durağan olmadığı tespit edilmiştir. Tablo 4'ün sonuçlarına göre durağan olmayan serilerin birinci fark1 alınarak seriler durağanlaştırılmıştır. Birinci farkı alınan serilerin istatistik ve $p$ değerleri Tablo 5 'te sunulmuştur. Sonuçlar, birinci farkları alınan değişken serilerin durağan olduğunu göstermektedir. 
Tablo: 5

Birim Kök Test Sonuçları (Birinci Fark)

\begin{tabular}{|c|c|c|c|c|c|c|}
\hline \multirow{2}{*}{ Değişkenler } & \multicolumn{2}{|c|}{ Levin, Lin ve Chu } & \multicolumn{2}{c|}{ Im, Pesaran ve Shin W-stat } & \multicolumn{2}{c|}{ ADF - Fisher Chi-square } \\
\cline { 2 - 7 } & Test ist & p-değeri & Test ist & p-değeri & Test ist & p-değeri \\
\hline GSYïHj & -3.73416 & $0.0001^{*}$ & -2.51835 & $0.0059^{*}$ & 25.5423 & $0.0125^{* *}$ \\
\hline Nüfusi & -11.2390 & $0.0000^{*}$ & -8.80884 & $0.0000^{*}$ & 81.8068 & $0.0000^{*}$ \\
\hline
\end{tabular}

Not: *, **ve *** istatistikleri sırasılla \%1, \%5 ve \%10 düzeyinde anlaml olduğunu göstermektedir.

Çalışmada Türkiye'nin E7 ülkeleri ile ticaret potansiyeli ticaret hacmi açısından regresyona tabi tutulmuştur. İlk olarak standart Çekim Modeli ile daha sonra modele sırasıyla eklenen Linder ve nüfus değişkenleri ile analiz yapılmıştır. Rassal etkiler modeli yaklaşımının uygulandığı panel regresyon analizleri EGLS (yatay kesit ağırlıklı) yöntemiyle Eviews 9 ekonometri programında yapılmıştır. Standart hataların düzeltilmesi amacıyla White cross section standart errors ve kovaryasyon yöntemi kullanılmıştır. Yapılan testlerin sonuçları Tablo 6, Tablo 7 ve Tablo 8'de gösterilmiştir.

EGLS (yatay kesit ağırlıklı) yöntemiyle tahmin edilen panel regresyon analizleri sonuçlarına göre, Basit/İlkesel Çekim Modeli ile açıklanmaya çalışılan Türkiye'nin E7 ülkeleri ile gerçekleştirdiği ticaret hacmi teoriye uygunluk göstermekte ve sabit katsayısı $\% 10$ düzeyinde, diğer katsayılar \%1 düzeyinde anlamlılık ifade etmektedir. Tablo 6'da yer alan $R^{2}$ ve olasılık (F-istatistik) değerlerine bakıldığında; $R^{2}$ değerinin 0,92 oranında bulunması ve olasılık (F-istatistik) değerinin 0,05 'ten küçük olması nedeniyle modelin istatistiksel olarak anlamlı olduğu görülmektedir. Tahmin sonuçlarına göre Türkiye'nin ve E7 ülkelerinin gayri safi yurtiçi hasılalarında meydana gelen \%1'lik artış ticaret hacmini sırasıyla \%1.42 ve \%0.27 artırmaktadır. Mesafe değişkeninde meydana gelen \%1'lik artışın ise ticaret hacmini \%1,90 azalttığı görülmektedir. Anderson (1979) ve Matyas (1998) Çekim Modelinin, karşılıklı ticaret akımlarını açıklamada başarılı ve öne çıkan bir yaklaşım olduğunu vurgulamış ve yazarlar "Ülkelerin ticaret hacminin ekonomik büyüklükleriyle doğru, aralarındaki mesafe ile ters yönlü bir ilişkisinin olduğu” (Tinbergen, 1962: 265) teorisini desteklemiştir. Tablo 6'da elde edilen sonuçlar doğrultusunda Çekim Modeli, Türkiye ve E7 ülkeleri arasında gerçekleşen dış ticareti analiz etme noktasında uygun bulunmuştur.

Tablo: 6

Model 1- Panel Regresyon Analiz Sonuçları

\begin{tabular}{|c|c|c|c|c|}
\hline \multicolumn{5}{|c|}{$\begin{array}{c}\text { Model 1 } \\
{\log D T_{i j t}=\beta_{0}+\beta_{1} \log G S Y I H_{i t}}+\beta_{2} \log G S Y I H_{j t}+\beta_{3} \log M e s a f e_{i j}+\epsilon_{i j t}\end{array}$} \\
\hline Değișkenler & Katsayısı & Std.Hata & t-istatistik & p-değeri \\
\hline Sabit & $-7.742748 * * *$ & 3.984617 & -1.943160 & 0.0546 \\
\hline $\log G S Y I H_{i t}$ & $1.421571^{*}$ & 0.103244 & 13.76907 & 0.0000 \\
\hline $\log _{\text {loSYIH }}{ }_{j t}$ & $0.275638^{* \prime}$ & 0.081821 & 3.368771 & 0.0010 \\
\hline logMesafe ${ }_{i j}$ & $-1.902321^{*}$ & 0.518688 & -3.667562 & 0.0004 \\
\hline İstatistikler & \multicolumn{4}{|c|}{$\begin{array}{l}R^{2}=0.928213 \text { D-Wİst. }=0.427871 \\
\text { F-ist }=474.1042 \text { Olasilık }(\text { F-istatistik })=0.000000\end{array}$} \\
\hline
\end{tabular}

Not: *, **ve *** istatistikleri strasıyla $\% 1, \% 5$ ve \%10 düzeyinde anlaml olduğunu göstermektedir. 
Çalışmada oluşturulan ikinci modelde Türkiye'nin E7 ülkeleri ile gerçekleştirdiği ticaret hacmi Basit/İlkesel Çekim Modeline Linder değişkeni eklenerek açıklanmaya çalışılmıştır. Tablo 7'de $R^{2}$ ve olasılık (F-istatistik) değerlerine bakıldığında; $R^{2}$ değerinin 0,92 oranında bulunması ve olasılık (F-istatistik) değerinin 0,05 'ten küçük olması nedeniyle modelin istatistiksel olarak anlamlı olduğu görülmektedir. Tahmin sonuçlarına göre Türkiye'nin ve E7 ülkelerinin GSYH'sinde \%1'lik artış ticaret hacmine sırasıyla \%1,45 ve $\% 0,25$ artırdığı ve mesafe değişkeninde meydana gelen \%1'lik artışın ise ticaret hacmini \%1,91 azalttığı görülmektedir. Ayrıca açıklayıcı değişken olarak eklenen Linder değişkenin istatistiksel olarak anlamlı bir etkisinin olmadığı sonucuna ulaşılmıştır. Linder değişkenin istatistiki olarak anlamlı ve negatif işaretli olması, karşılıklı ticarette Linder hipotezini destekler sonuç elde edilmesini ifade etmektedir. Choi (2002), Baltagi, Egger ve Pfaffermayr (2003) ve Thursby ve Thursby (1987) Linder Hipotezinin destekler sonuç elde etmişlerdir. $\mathrm{Bu}$ çalışmada ise negatif işarete sahip olan Linder değişkenin, dış ticaret hacmi üzerinde istatistiki olarak anlamlı bir etkisinin olmadığı görülmüştür.

\section{Tablo: 7}

Model 2- Panel Regresyon Analiz Sonuçları

\begin{tabular}{|c|c|c|c|c|}
\hline \multicolumn{5}{|c|}{$\begin{array}{c}\text { Model 2 } \\
\operatorname{LogDT}_{i j t}=\beta_{0}+\beta_{1} \log G S Y I H_{i t}+\beta_{2} \log G S Y I H_{j t}+\beta_{3} \log \text { Mesafe }_{i j}+\beta_{4} \log \operatorname{Linder}_{i j t}+\epsilon_{i j t}\end{array}$} \\
\hline Değişkenler & Katsayısı & Std.Hata & t-İstatistik & p-Değeri \\
\hline Sabit & $-7.812188^{* * * *}$ & 4.615882 & -1.692458 & 0.0934 \\
\hline $\operatorname{logGSYIH}_{i t}$ & $1.450436^{\mathrm{m}}$ & 0.106528 & 13.61551 & 0.0000 \\
\hline $\operatorname{logGSYIH}_{j t}$ & $0.256579^{*}$ & 0.083509 & 3.072463 & 0.0027 \\
\hline $\operatorname{logMesafe}_{i j}$ & $-1.910037^{*}$ & 0.626643 & -3.048045 & 0.0029 \\
\hline Linder $_{i j t}$ & -0.001834 & 0.002104 & -0.871551 & 0.3854 \\
\hline İstatistikler & \multicolumn{4}{|c|}{$\begin{array}{l}R^{2}=0.929426 \text { D-Wİst. }=0.436321 \\
\text { F-ist }=358.8700 \text { Olasilık (F-istatistik })=0.000000\end{array}$} \\
\hline
\end{tabular}

Not: *, **ve *** istatistikleri sırastyla \%1, \%5 ve \%10 düzeyinde anlaml olduğunu göstermektedir.

Son olarak kurulan üçüncü modelde ise Türkiye'nin E7 ülkeleri ile gerçekleştirdiği ticaret hacmi Basit/İlkesel Çekim Modeline nüfus değişkeni eklenerek açıklanmaya çalışılmıştır. Tablo 8'de $R^{2}$ ve olasılık (F-istatistik) değerlerine bakıldığında; $R^{2}$ değerinin 0,93 oranında bulunması ve olasılık (F-istatistik) değerinin 0,05 'ten küçük olması nedeniyle modelin istatistiksel olarak anlamlı olduğu görülmektedir. Tahmin sonuçlarına göre modele Türkiye'nin nüfus değişkenin istatistiksel olarak anlamlı olmadığı sonucuna ulaşılmıştır. Modelde yer alan diğer değişkenlerin ise istatistiksel olarak anlamlı etkilerinin olduğu görülmektedir. Bu değişkenlerden Ayrıca Türkiye'nin ve E7 ülkelerinin GSYH'sinde ve E7 ülkelerinin nüfusunda \%1'lik artışın ticaret hacmine sırasıyla $\% 1,33, \% 0,20$ ve $\% 0,64$ artırdığ 1 ve mesafe değişkeninde meydana gelen \%1'lik artışın ise ticaret hacmini \%1,61 azalttı̆̆1 görülmektedir. 
Tekin, M. \& F. Merdivenci (2022), "E7 Ülkeleri ile Türkiye Arasındaki Dış Tícaretin

Panel Veri Analizi: Çekim Modeli Yaklaşımı”, Sosyoekonomi, 30(51), 407-426.

Tablo: 8

Model 3- Panel Regresyon Analiz Sonuçları

\begin{tabular}{|c|c|c|c|c|}
\hline \multicolumn{5}{|c|}{$\begin{array}{c}\text { Model 3 } \\
{\log D T_{i j t}=\beta_{0}+\beta_{1} \log G S Y I H_{i t}+\beta_{2} \log G S Y I H_{j t}}+\beta_{3} \operatorname{logNufus_{it}}+\beta_{4} \operatorname{logNufus_{jt}}+\beta_{5} \log \text { Mesafe }_{i j}+\epsilon_{i j t}\end{array}$} \\
\hline Değişkenler & Katsayısı & Std.Hata & t-İstatistik & p-Değeri \\
\hline Sabit & $-33.15962^{*}$ & 10.74149 & -3.087061 & 0.0026 \\
\hline $\log _{\text {GSYIH }}{ }_{i t}$ & $1.332925^{*}$ & 0.061025 & 21.84218 & 0.0000 \\
\hline $\log G S Y I H_{j t}$ & $0.201877^{\star}$ & 0.066264 & 3.046531 & 0.0029 \\
\hline $\operatorname{logMesafe}_{i j}$ & $-1.616557^{*}$ & 0.608096 & -2.658391 & 0.0090 \\
\hline $\operatorname{logNufus}_{i t}$ & 0.808986 & 0.740812 & 1.092025 & 0.2773 \\
\hline $\operatorname{logNufus} j t$ & $0.649102^{* * *}$ & 0.345211 & 1.880302 & 0.0628 \\
\hline İstatistikler & \multicolumn{4}{|c|}{$\begin{array}{l}R^{2}=0.934213 \text { D-Wíst. }=0.438707 \\
\text { F-ist }=306.7310 \text { Olasilik }(\text { F-istatistik })=0.000000\end{array}$} \\
\hline
\end{tabular}

Not: *, **ve *** istatistikleri strasılla \%1, \%5 ve \%10 düzeyinde anlamlı olduğunu göstermektedir.

\section{Sonuç ve Öneriler}

$\mathrm{Bu}$ çalışmanın temel amacı, Türkiye ve E7 ülkeleri arasında gerçekleşen ticaret hacmine etki eden faktörleri belirlemek ve Çekim Modelinin ticaret hacmini açıklamaya uygun olup olmadığını panel veri analiz ile test etmektir. Bu amaç doğrultusunda dış ticaret hacmine etkisi olabilecek değişkenlerden, ülkelerin GSYH'si, nüfusu, Linder değişkeni ve ülkelerin arasında coğrafi uzaklıktan kaynaklanan mesafe değişkeni Çekim Modeline eklenerek üç farklı logaritmik model oluşturulmuş ve panel veri analiz yöntemiyle sonuçlar elde edilmiştir.

Çalışmada Türkiye'nin E7 ülkeleri ile gerçekleştirdiği dış ticaretin Çekim Modeli kullanılarak incelenmesinin nedeni, gelişmekte olan E7 ülkelerinin Türkiye ile artan diş ticaret rakamlarıdır. Bir diğer neden ise Price Waterhouse Cooper firmasının 2017 yılında yayımladığ1 “2050'de Dünya” başlıklı raporunda, E7 ülkelerinin 2016 yılındaki küresel GSYH'nde \%37'lik bir paya sahip olduğu ve bu payın 2050 yılında \%48'e yükseleceğinin vurgulanmasıdır. E7 ülkelerinin dünya ticaretinde hızla artan dış ticaret payı ve Türkiye'nin bu ülkelerle gerçekleştirdiği dış ticaret hacminin özellikle son yıllardaki artışı nedeniyle, süreci daha iyi analiz edebilmek ve güncel verileri yansıtabilmek adına çalışmada 20002018 zaman aralığ

Yapılan analiz sonuçlarına göre 2000-2018 döneminde Türkiye'nin E7 ülkeleri ile gerçekleştirdiği ticaret hacmi Basit/İlkesel Çekim Modeline uygunluk göstermiştir. Dış ticaret hacmi hem Türkiye'nin hem de E7 ülkelerinin GSYH katsayıları ile pozitif yönlü ve anlamlı bir ilişki göstermiştir. Buna göre Türkiye'nin ve E7 ülkelerinin GSYH'sinde gerçekleşecek \%1'lik artış ticaret hacmini sırasıyla \%1,45 ve \%0,25 oranında artıracaktır. Diğer bağımsız değişken olan mesafe ise Türkiye ile E7 ülkeleri arasında gerçekleşen ticaret hacmine negatif yönlü ve anlamlı etki ettiği görülmüştür. Bu durumda mesafe değişkeninden kaynaklanan uzaklığın artması ile dış ticaret hacminin azalması söz konusudur.

Dış ticaret hacminin bağımlı değişken olduğu ve Basit/İlkesel Çekim Modeline Linder değişkeni eklenerek kurulan modele göre GSYH değişkenleri pozitif yönlü ve anlamlı iken mesafe değişkeni negatif yönlü ve anlamlı bir etki etmiştir. Ülkelerin kişi başına 
düşen gelirleri arasındaki farkı ifade eden Linder değişkenin ise negatif yönlü olduğu ve dış ticaret hacmi üzerinde istatistiki olarak anlamlı bir etkisinin olmadığı görülmüştür. Bu durum gelir farklarındaki azalmaların gerçekleşen ticaret akışında etki yaratmadığı şeklinde yorumlanabilmektedir.

Son olarak Basit/İlkesel Çekim Modeline toplam talebi gösteren nüfus değişkeni eklenerek oluşturulmuş model, istatistiki olarak anlamlı çıkmıştır. Türkiye'nin ve E7 ülkelerinin GSYH'si ile E7 ülkelerinin nüfusunun bir arada değerlendirildiği modelde bağımsız değişkenlerin dış ticaret hacmi üzerinde pozitif yönlü ve anlamlı bir etkisi olduğu sonucuna varılmıştır. Mesafe değişkenin ise negatif yönde ve anlamlı bir etkisi olmuştur. Modele eklenen bağımsız değişkenlerden Türkiye'nin nüfusunun ise dış ticaret hacmine anlamlı bir etkisinin olmadığ 1 saptanmıştır. Toplam talebi gösteren nüfus değişkenin pozitif ve anlamlı olması E7 ülkelerinin nüfusu arttıkça daha fazla mal ihracatı ve ithalatı gerçekleştirdiği şeklinde yorumlanabilmektedir.

Türkiye'nin E7 ülkeler ile arasındaki dış ticaret rakamlarının artması, ülkenin PWC tarafından yapılan 2050 yılı için tahmini küresel ekonomi güç sıralamasındaki konumuna erişmesini kolaylaştıracağı gibi ülkeye ekonomik açıdan birçok fayda sağlayacaktır. Bu çerçevede 2018 yılları itibariyle gerçekleştirilen diş ticaret rakamı 64.263 milyar dolar olsa da E7 ülkeleri ile gerçekleştirilmesi gereken potansiyel ticaret hacminin daha yüksek olmasını beklemek yanlış olmayacaktır. Bu doğrultuda Türkiye'nin dış ticaret hacmini artırmak için ekonomik büyüklük ölçütlerinden biri olan GSYH oranın da artırması gerekmektedir. Bu amaçla Türkiye, GSYH oranlarını artırmak için temel olarak üretim miktarını artırabilir.

Türkiye'nin E7 ülkeleri ile gerçekleştirdiği dış ticaret kalemlerinde yer alan ürün gruplarına bakıldığında Türkiye'nin genel olarak yüksek katma değerli ürünleri ithal ettiği görülmektedir. Bu ürünlerin yüksek maliyetli olması ve Türkiye'nin ihraç kaleminin genel olarak ithal kalemine göre değer açısından düşük maliyetli ürünlerin oluşturması ülkenin dış ticaret açığını artırmaktadır. Bu açıdan Türkiye'nin ekonomisi için artırması gereken ürün miktarlarının içerisinde ham ve yarı mamul olan ürünlerin işlenmesi ve katma değerlerinin artırılması ülkenin dış ticaret açığını azaltabileceği gibi GSYH oranlarının yükselmesini de sağlayabilir. Ayrıca, Michaely (1977) ve Balassa (1978) gibi iktisatçılar da ihracat ve büyüme arasındaki pozitif ilişkinin olduğu sonucunu vurgulamışlardır. Bu sebeple Türkiye'nin ihracatını artırması ekonomik büyümesi açısından önem arz edebilir.

$\mathrm{Bu}$ çalışma belirli açıklayıcı parametreler ile kurulduğundan gelecekte bu alanda yapılan çalışmalar için birkaç öneride bulunmak yerinde olacaktır. Gelecekte yapılan çalışmalar; genişletilmiş Çekim Modelinde açıklayıcı parametreler arasında yer alan ekonomik bütünleşmelerin etkisi, tarifeler ve tarife dişı engeller, siyasi rejimlerdeki benzerlik/ farklılık, teknolojik yakınlık/ uzaklığa ilişkin çeşitli değer ve rasyolar, altyapı donanımı, kültürel benzerlik, dışa açıklık oranı ve beşerî sermayeye ilişkin çeşitli rasyolar ile model kurarak Türkiye ve E7 ülkeleri arasındaki dış ticaret akışına etkilerini analiz edebilirler. Ayrıca Türkiye'nin gelişmiş ülkelerden oluşan G7 ülkeleri gerçekleştirdiği dış 
Tekin, M. \& F. Merdivenci (2022), "E7 Ülkeleri ile Türkiye Arasındaki Dış Tícaretin Panel Veri Analizi: Çekim Modeli Yaklaşımı”, Sosyoekonomi, 30(51), 407-426.

ticaret akışı Çekim Modeli ile analiz edilip bu araştırmanın verilerinden elde edilen sonuçlar ile karşılaştırılacağı bir araştırma ortaya konulabilir.

\section{Kaynaklar}

Aitken, N.D. (1973), "The Effect of the EEC and EFTA on European Trade: A Temporal CrossSection Analysis", American Economic Association, 63(5), 881-892.

Anderson J.E. \& E. Wincoop (2003), "Gravity with Gravitas: A Solution to the Border Puzzle", NBER Working Paper Series, Paper No. 8079.

Anderson, J.E. (1979), “A Theoretical Foundation for the Gravity Equation”, American Economic Review, 69(1), 106-116.

Armington, P.S. (1969), "A Theory of Demand for Products Distinguished by Place of Production", IMF Staff Papers, 16(1), 159-176.

Ata, S. (2012), "Türkiye'nin İhracat Potansiyeli: Çekim Modeli Çerçevesinde Bir İnceleme”, International Conference on Eurasian Economies, 13 Ekim, Kazakistan, 276-282.

Bai, J. \& C. Kao (2006), "On the Estimation and Inference of a Panel Cointegration Model with Cross-Sectional Dependence", Contributions to Economic Analysis, 274, 3-30.

Balassa, B. (1978), "Exports and Economic Growth Further Evidence”, Journal of Development Jiconomics, 5,181-189.

Baldwin, R. \& D. Taglioni (2011), "Gravity Chains: Estimating Bilateral Trade Flows When Parts And Components Trade Is Important”, NBER Working Paper, 16672.

Baltagi, B.H. (2005), Econometric Analysis of Panel Data, Third Edition, John Wiley \& Sons Inc., New Jersey.

Baltagi, B.H. et al. (2003), “A Generalized Design For Bilateral Trade Flow Models”, Economics Letters, 80, 391-397.

Banerjee, A. \& J.L. Carrion-i-Silvestre (2006), "Cointegration in Panel Data with Breaks and CrossSection Dependence”, in: ECB Working Paper Series, European Central Bank.

Batra, A. (2006), "India's Global Trade Potential: The Gravity Model Approach”, Global Economic Review, 35(3), 327-361.

Baytar, R.A. (2012), "Türkiye ve BRIC Ülkeleri Arasındaki Ticaret Hacminin Belirleyicileri: Panel Çekim Modeli Analizi”, İstanbul Ticaret Üniversitesi Sosyal Bilimler Dergisi, 11(21), 403-424.

Bergstrand, J.H. (1985), "The Gravity Equation in International Trade: Some Microeconomic Foundations and Empirical Evidence", The Review of Economics and Statistics, 67(3), 474-481.

Bergstrand, J.H. (1989), "The Generalized Gravity Equation, Monopolistic Competition, and the Factor-Proportions Theory in International Trade", Review of Economics and Statistics, 71(1), 143-153.

Breuss F. \& P. Egger (1999), "How Reliable Are Estimations of East-West Trade Potentials Based on Cross-Section Gravity Analyses?", Empirica, 26(2), 81-94.

Brun, J.F. et al. (2005), "Has Distance Died? Evidence from a Panel Gravity Model", The World Bank Economic Review, 19(1), 99-120. 
Carrère, C. (2006), "Revisiting The Effects of Regional Trade Agreements on Trade Flows With Proper Specification of The Gravity Model", European Economic Review, 50(2), 223247.

Choi, C. (2002), "Linder hypothesis revisited", Applied Economics Letters, 9, 601-605.

De Benedictis, L. \& D. Taglioni (2011), "The gravity model in international trade”, in: L. De Benedictis \& L. Salvatici (eds.), The Trade Impact of European Union Preferential Policies: An Analysis Through Gravity Models, (55-90), Springer, (Chapter 4).

Deardorff, A. (1998), "Determinants of Bilateral Trade: Does Gravity Work in a Neoclassical World?”, in: J.A. Frankel (ed.), In The Regionalization of the World Economy, (7-32), Chicago: University of Chicago.

Demiral, M. vd. (2016), "Petrol Gelirleri ve Ekonomik Büyüme: Seçilmiş Petrol Zengini Gelişmekte Olan Ülkeler Üzerine Bir Panel Veri Analizi”, Sosyoekonomi, 24(27), 85-102.

Dinçer, G. (2013), "Dış Ticaret Kuramında Çekim Modeli: Türkiye-AB Ticaretinin Analizi”, Doktora Tezi, Gazi Üniversitesi Eğitim Bilimleri Enstitüsü, Ankara.

Dinçer, G. (2014), “Dış Ticaret Kuramında Çekim Modeli”, Ekonomik Yaklaşım, 24(88), 1-34.

Dinh, T B. et al. (2011), “Applying Gravity Model to Analyze Trade Activities of Vietnam", External Economics Review, No: 69.

Egger, P. (2002), "An Econometric View on the Estimation of Gravity Models and the Calculation of Trade Potentials", The World Economy, 25(2), 297-312.

Eichengreen, B. \& D. Irwin (eds.) (1998), The Role of History in Bilateral Trade Flows, The University of Chicago Press, Chicago, London.

Endoh, M. (1999), "Trade creation and trade diversion in the EEC, the LAFTA and the CMEA: 1960-1994”, Applied Economics, 31(2), 207-216.

Fidrmuc, J. (2009), "Gravity Models in Integrated Panels”, Empir Econ, 37,435-446.

Filippini, C. \& V. Molini (2003), "The Determinants of East Asian Trade Flows: A Gravity Equation Approach", Journal of Asian Economics, 14(5), 695-711.

Helpman, E. \& P. Krugman (1985), Market Structure and Foreign Trade, Cambridge: MIT Press.

Helpman, E. et al. (2008), "Estimating Trade Flows: Trading Partners And Trading Volumes", NBER Working Paper, 12927.

Holly, S. et al. (2010), “A Spatio-Temporal Model of House Prices in the USA”, Journal of Econometrics, 158, 160-173.

Hsiao, C. (2005), “Why Panel Data?”, The Singapore Economic Review, 50(2), 143-154.

Işık, N. (2016), “Türkiye ile Şanghay İşbirliği Örgütü Arasındaki Ticaret Akımlarının Panel Çekim Modeli İle Tahmini”, Uluslararası İktisadi ve İdari Incelemeler Dergisi, (17), 151-174.

Karagöz, K. (2008), “Türkiye'nin Turizm Potansiyeli: Çekim Modeli Yaklaşımı”, Anatolia: Turizm Araştırmaları Dergisi, 19(2), 149-156.

Kepaptsoglou, K. et al. (2010), "The Gravity Model Specification for Modeling International Trade Flows and Free Trade Agreement Effects: A 10-Year Review of Empirical Studies", The Open Economics Journal, 3, 1-13.

Khandare, V.B. (2011), "Impact of Globalization on International Trade (With Special Reference to India)", International Journal of Trade and Services, 3(1), 1-14. 
Tekin, M. \& F. Merdivenci (2022), "E7 Ülkeleri ile Türkiye Arasındaki Dış Tícaretin Panel Veri Analizi: Çekim Modeli Yaklaşımı”, Sosyoekonomi, 30(51), 407-426.

Kimura, F. \& H. Lee (2006), “The Gravity Equation in International Trade in Services”, Review of World Economics, 142(1), 93-121.

Koy, A. vd. (2019), Ekonometri Uygulamaları, Seçkin Yayıncılık, Ankara.

Lampe, M. (2008), "Bilateral Trade Flows in Europe, 1857-1875: A New Dataset”, Res Econ Hist., 26(1), 81-155.

Leamer, E. \& J. Levinsohn (1995), “International Trade Theory: The Evidence”, NBER Working Paper No. 4940, 1-54.

Michaely, M. (1977), "Exports and Growth An Empirical Investigation", Journal of Development Economics, 4, 49-53.

Nguyen, K. (2009), "Gravity Model by Panel Data Approach An Empirical Application with Implications for the ASEAN Free Trade Area", ASEAN Economic Bulletin, 26(3), 266277.

Nitsch, V. (2006), “Does the G7/G8 promote trade?”, Economics Letters, 94, 136-140.

Oguledo V. \& C.R. Macphee (1994), "Gravity Models: A Reformulation and an Application to Discriminatory Trade Arrangements", Applied Economics, 26(2), 107-120.

Paas, T. (2000), "The Gravity Approach for Modeling International Trade Patterns for Economies in Transition", IAER, 6(4), 633-648.

Paas, T. (2003), "Regional Integration and International Trade in the Context of EU Eastward Enlargement", Hamburgisches Welt-Wirtschafts-Archiv (HWWA) Hamburg Institute of International Economics, Discussion Paper No. 218: 1-30.

Pesaran, M.H. (2015), Time Series and Panel Data Econometrics, Oxford University Press.

Porojan, A. (2001), “Trade Flows and Spatial Effects: The Gravity Model Revisited”, Open Econ Rev, 12, 265-280.

Pöyhönen, P. (1963), “A Tentative Model for the Volume of Trade between Countries”, Weltwirtschaftliches Archiv, Bd. 90, 93-100.

Price Waterhouse Coopers (2008), The World in 2050: Beyond The BRIC's A Broader Look At Emerging Market Growth Prospects, PWC London UK.

Price Waterhouse Coopers (2017), The Long View How will the Global Economic Order Change by 2050, PWC London UK.

Rasoulinezhad, E. \& G. Seong (2016), “A Panel Data Analysis of South Korea's Trade with OPEC Member Countries: The Gravity Model Approach", Iran.Econ.Rev., 20(2), 203-224.

Samadder, S. et al. (2012), "Scaling Analysis of Prime Stock Exchange Indices of the Emerging Seven (E7) Countries", Int J Appl Comput Sci Math, 2(1), 12-22.

Sevüktekin, M. \& M. Nargeleçekenler (2010), Ekonometrik Zaman Serileri Analizi, Geliştirilmiş 3. Bask1, Nobel Yayın, İstanbul.

Sorhun, E. (2013), “Türkiye'nin Eksik Dış Ticareti, Ticari Potansiyeli ve Yeni Fırsatlar”, DEÜ İ̈BF Dergisi, 28(1), 25-47.

Stack, M.M. (2009), "Regional Integration and Trade: Controlling for Varying Degrees of Heterogeneity in the Gravity Model", The World Economy, 32(5), 772-789.

Tataoğlu, F.Y. (2018), Panel Veri Ekonometrisi: Stata Uygulamal, Beta Basım Yayım, İstanbul.

Tatlıcı, Ö. \& A. Kızıltan (2011), "Çekim Modeli: Türkiye'nin İhracatı Üzerine Bir Uygulama”, Atatürk Ü. İBF Dergisi, 10. Ekonometri ve İstatistik Sempozyumu Özel Sayıs1, 287-299. 
Thursby, J.G. \& M.C. Thursby (1987), "Bilateral Trade Flows, the Linder Hypothesis, and Exchange Risk", The Review of Economics and Statistics, 69(3), 488-495.

Tinbergen, J. (1962), Shaping the World Economy, New York, The Twentieth Century Fund.

Wall, H.J. (1999), Using The Gravity Model to Estimate The Costs of Protection, Federal Reserve Bank of St. Louis.

Westerlund, J. (2005), "New Simple Tests for Panel Cointegration”, Econometric Reviews, 24(3), 297-316.

World Bank (2020), <https://data.worldbank.org/>, 15.07.2020.

Yaşar, H.N. (2011), “Avrupa Birliği ve Türkiye Arasındaki Gümrük Birliği Çerçevesinde Türkiye İhracatının Çekim Modeli Uygulaması”, Yüksek Lisans Tezi, Dokuz Eylül Üniversitesi Sosyal Bilimler Enstitüsü, İzmir.

Zarzoso, I.M. \& F.N. Lehmann (2003), “Augmented Gravity Model: An Empirical Application to Mercosur-European Union Trade Flows”, Journal of Applied Economics, 6(2), 291-316. 